\section{Miksi VANHUUS ON MUODOSTUNUT ONGELMAKSI?}

Jari Pirhonen: sosiaaligerontologian dosentti, Helsingin yliopisto, Valtiotieteellinen tiedekunta

Timo Airaksinen: Hyvinvointivaltion hylkäämät. Ikääntyneiden hoidon etiikka. Bazar Kustannus Oy, Helsinki. 2020 L $270 \mathrm{~s}$.

Hyvinvointivaltion hylkäämät on keskimmäinen osa suomalaisten arvojen kriisiä käsittelevää filosofi Timo Airaksisen trilogiaa. Airaksinen pureutuu teoksessaan näin sosiaaligerontologin silmin tärkeään ja usein ihmetyttäväänkin aiheeseen pohtiessaan, mihin vanhojen ihmisten arvostus on Suomesta kadonnut. Vanhukset saavat osansa huomiosta ja julkisesta keskustelusta varsinkin kaikkien vaalien alla, mutta juhlapuheista huolimatta vanhustenhoidon tilanne pysyy huonona tai pikemminkin huononee koko ajan. Riippumatta siitä, minkä värinen hallitus maassa kulloinkin sattuu olemaan.

Viimeksi vuonna 2019 käytiin kiivasta julkista keskustelua vanhustenhoidon heikosta tilasta, kun valvontaviranomaiset asettivat monia pitkäaikaishoitoyksiköitä ympäri maan toimintakieltoihin, erityisesti liian vähäisen henkilökunnan ja puutteellisen lääkehoito-osaamisen vuoksi. Valelääkärit saivat tuolloin rinnalleen haamuhoitajat, eli henkilöstön, joka oli merkitty työvuorolistoihin todellisen tilanteen vastaisesti. Paljon porua käytiin, kanteluiden ja tarkastuskäyntien määrät nousivat huimasti, ja saatiinpa lopulta lakiinkin sitova hoitajamitoitus vanhusten pitkäaikaishoitoon. Sekin on kuitenkin vuosien prosessi eikä poista perusongelmaa. Kirjassaan Airaksinen ihmettelee, syystäkin ja filosofin tarkkanäköisyydellä, miten on mahdollista, että kaikesta tiedosta huolimatta tilanne vain huononee.

Airaksinen on rakentanut teoksensa neljän pääluvun varaan. Ensimmäisessä luvussa hän pohtii onnellisen vanhuuden mahdollisuutta. Läpi teoksen esiteltävien ajatuskokeiden ja muiden filosofien käyttämien argumentaatiomenetelmien avulla lukijalle osoitetaan onnellisuuden suhteellisuus ja vanhuksen hyvän elämän reunaehdot. Paljastamatta liikaa sisältöä voin todeta, että huutia saavat ikääntymiseen liitetyt mielikuvat, vanhuspalvelujärjestelmä, palveluista vastaavat poliitikot ja vanhushoivan tuottajat. Unohtamatta teoksen pääasiaa eli suomalaisen arvomaailman muutosta tai kriisiä. Vanhuuden nykyinen vertautuminen sairauteen puhuttaa paljon myös meitä ikääntymisen tutkijoita.

Toisessa luvussa Airaksinen käsittelee eliniän pitenemisen luomaa paradoksia: pitkä ikä on ihmisen vuosisatainen päämäärä ja samalla se näyttää käyvän yhteiskunnalle liian kalliiksi, ja on siten epätoivottavaa. Tästä filosofi muotoilee ikääntymisen reaaliolemuksellisen maksiimin: elä vanhaksi ja elä yhä kurjemmin! Luvun parasta antia onkin kuvatun paradoksin syiden puntaroiminen. Luvussa selvitellään, mihin perustuu nuorempien sukupolvien $\mathrm{ky}-$ vyttömyys kuvitella itsensä paljon apua tarvitsevan vanhuksen asemaan. Luku tarjoaa paljon näkökulmia ja oivalluksia kipuiluumme vanhuuden kanssa. 
Kolmas luku käsittelee vanhan katoavaa identiteettiä. Airaksinen esittää hyvää pohdintaa identiteetin muodostumisen ja katoamisen yhteydestä toisilta ihmisiltä saatavaan tunnustukseen. Mieleen jäi vahvasti filosofin kielikuva ihmisen elämästä läpi avaruuden ja ajan kiemurtelevana makkarana, jossa jokainen ajallispaikallinen makkaransiivu liittyy edeltäneeseen siivuun siten, että syntyy pitkä pötkö. Makkarapötkön eri vaiheissa ihmisen toisilta saama tunnustus ja kunnioitus vaihtelevat. Lopussa häämöttää näkymättömyys, josta omassa tutkimuksessani olen käyttänyt käsitettä sosiaalinen kuolema. Luvun lopussa käsitellään vielä erikseen vanhuuteen liitettyjä moninaisia stigmoja maailmankirjallisuudesta nostettujen esimerkkien kautta.

Neljättä lukua voidaan varmasti pitää teoksen nimilukuna. Siinä filosofi pureutuu jo otsikossa mainittuun hyvinvointivaltion epäonnistumiseen vanhusten hoivan kohdalla. Aluksi käsitellään tekoälyn ja teknologian lobbaajien suuret lupaukset vanhustenhoidon kontekstissa tyylillä, josta voi kuvitella kirjailijan kirjoittavan sytyttävästä aiheesta. Hoivarobotiikan etiikkaa tutkineena tunnustan nauttineeni Airaksisen tavasta osoittaa, että teknologisten ratkaisujen tarjoaminen sosiaalisiin ongelmiin ei ehkä ole kovin hyvä idea Vanhustenhoidon teknologisen ratkaisuyrityksen kautta päädytään siihen, mikä lopulta on tärkeintä: armo, sääli, lohtu, hoiva ja toivo. Kirjan loppu on tekstiä, jonka toivoisi löytävän mahdollisimman monen ihmisen käsiin.

Kirja on kirjoitettu vakavasta aiheesta, mutta teksti on arkikielistä ja siksi helposti luettavaa, kunhan ensin tot- tuu Airaksisen tyyliin kirjoittaa. Alussa gerontologin pulssini kiihtyi useaan otteeseen filosofin käyttämistä ilmauksista ja vanhuuden kuvauksista, kunnes aloin ymmärtää tekstin hirtehishumoristista luonnetta. Jostakin syystä kirjan sanoma tiivistyi minulle erityisesti kahdessa Airaksisen virkkeessä: "Tunteiden hyljeksintä johtaa tunteettomuuteen" ja "nuori saattaa joutua vaikeuksiin, vanha joutuu joka tapauksessa". Vanhuuden pelko ei ole viisauden alku. Viisauden alku on realiteettien tunnustaminen - ainoa keino välttää kuoleminen on vanheneminen.

\section{KATTAVA KÄSIKIRJA LAPSI- PERHEIDEN KÖYHYYDESTÄ JA HUONO-OSAISUUDESTA}

Niko Eskelinen: väitöskirjatutkija, Turun yliopisto, INVEST -lippulaiva, vieraileva tutkija, Terveyden ja hyvinvoinnin laitos

Johanna Kallio \& Mia Hakovirta (toim.): Lapsiperheiden köyhyys ja huono-osaisuus. Vastapaino, Tampere. 2020, 330 s.

Suomalainen yhteiskunta on vaurastunut merkittävästi reilun sadan vuoden ajan. Suuri enemmistö väestöstä voi sosiaalisesti, taloudellisesti ja terveydellisesti kenties paremmin kuin koskaan aikaisemmin. Edeltävästä huolimatta hyvinvoinnin monia myönteisiä kehityskulkuja varjostaa lapsuuden eriarvoistuminen ja lapsiperheiden elämän mahdollisuuksien eriytyminen. Viimeisten vuosikymmenten aikana lapsiperheköyhyys on kasvanut ja lasten taloudellinen hyvinvointi heikentynyt. 
Turun yliopiston sosiaalityön professori Johanna Kallion ja dosentti Mia Hakovirran toimittamassa tuoreessa teoksessa tarkastellaan määrällisiin empiirisiin aineistoihin nojaten lapsiperheiden köyhyyttä ja huono-osaisuutta sekä haavoittuvan perhetaustan yhteyttä lasten hyvinvointiin ja aikuisuuden asemiin. Kokonaisuudessaan teos on tarkkanäköinen kuvaus lapsiperheiden köyhyydestä ja huono-osaisuudesta Suomessa.

Kokoomateoksen kirjoittamiseen on osallistunut laaja joukko alan tutkijoita. Artikkelit ovat hyvin kirjoitettuja ja ne muodostavat koherentin kokonaisuuden. Kokonaisuus jakautuu kolmeen osaan. Ensimmäinen osa kuvaa lapsiperheiden köyhyyttä ja huono-osaisuutta Suomessa. Lapsiperheköyhyyden kehityksen ohella osiossa tarkastellaan ruoka-apuun turvautuvia lapsiperheitä ja lasten erkanevia elämänkulkuja perhedynamiikan näkökulmasta. Teoksen toisessa osassa ääni annetaan lapsille. Osion luvuissa käsitellään lapsiaineistoihin tukeutuen vanhempien huono-osaisuuden yhteyttä lasten subjektiiviseen hyvinvointiin ja vanhempien huono-osaisuuden yhteyttä lasten ja nuorten tulevaisuuden odotuksiin ja voimavaroihin. Kolmannessa osiossa keskitytään huono-osaisuuden ylisukupolvisuuteen. Osion luvut käsittelevät vanhempien huono-osaisuuden yhteyttä koulupudokkuuteen ja toimeentulotuen asiakkuuteen, jonka lisäksi huomiota kiinnitetään kodin ulkopuolelle sijoitettujen lasten aikuisuuden asemien rakentumiseen. Nostan näistä näkökulmista jäljempänä esiin vain muutamia.
Teos lähtee liikkeelle ilmiön kartoittamisesta ja kokoomateoksen kannalta keskeisten käsitteiden, köyhyyden ja huono-osaisuuden, määrittelemisestä. Lapsiperheiden köyhyys ja huono-osaisuus ovat moniulotteisia ilmiötä ja niitä voidaan lähestyä ja mitata monin eri tavoin. Erilaiset mittarit, kuten lasten suhteellinen köyhyysaste, lasten subjektiivinen kokemus köyhyydestä ja huono-osaisuudesta tai esimerkiksi vanhempien toimeentulotuen asiakkuus painottavat eri asioita, minkä vuoksi indikaattoreiden avaaminen on tärkeää ja tarpeellista. Huolellisesti kirjoitettu johdanto pohjustaa tulevia lukuja ja avaa hyvin lapsiperheitä koskevan köyhyys- ja huono-osaisuustutkimuksen lähtökohtia.

Kokoomateoksen ensimmäinen osa alkaa Minna Salmen artikkelilla Lapsiperheiden köyhyys pitää yllä köyhyyden kierrettä, joka asettaa lapsiperheitä koskevan köyhyyden laajempaan kehykseen. Salmi tarkastelee lapsiperheköyhyyden kehitystä ajassa, kuvaa köyhyyttä erilaisissa lapsiperheissä sekä valottaa ilmiön taustalla olevia poliittiseen päätöksentekoon kytkeytyviä tekijöitä. Suomessa lapsiperheköyhyys vähentyi 1960-luvulta 1990-luvun lamaan saakka, jonka jälkeen lapsiperheiden keskimääräinen köyhyysaste on lähes kolminkertaistunut. Erityisesti yksihuoltajaperheisiin paikantuva pienituloisuus on kasvanut voimakkaasti. Salmen mukaan lapsiperheköyhyyden taustalla on erityisesti niukkaan koulutukseen, työelämän muutokseen ja työttömyyteen liittyvät tekijät, joita ovat edelleen vahvistaneet viimeisten vuosikymmenten aikana "sosiaalipolitiikan suunnanmuutoksen" hengessä 
tehdyt poliittiset päätökset, joilla on heikennetty lapsiperheiden toimeentuloa ja (perus)palveluita.

Kokonaisuuden kannalta kiinnostavan osion muodostavat teoksen toisen osion artikkelit vanhempien huono-osaisuuden yhteydestä lapsen subjektiivisen hyvinvointiin (Enna Toikka \& Leena Haanpää) ja vanhempien huono-osaisuuden yhteydestä lasten ja nuorten tulevaisuuden voimavaroihin ja ajatuksiin tulevaisuudesta (Leena Koivusilta). Lapsinäkökulmainen ja lapsilähtöisiä aineistoja hyödyntävä tutkimus avaa kiinnostavan näkökulman köyhyystutkimukseen ja lisää ymmärrystä köyhyydestä ja sen välillisistä ja välittömistä seurauksista lasten kokemusmaailmasta käsin. Lohdullista on, että Toikan ja Haanpään mukaan valtaosa lapsista voi verrattain hyvin ja arvioi hyvinvointinsa korkeaksi, joskin hyvinvointi on heikompaa lasten keskuudessa, jotka ovat raportoineet perheen taloudellisten resurssien olevan niukkoja. Koivusillan mukaan perheiden huono-osaisuus näyttäisi olevan yhteydessä lasten ja nuorten heikompaan itsetuntoon ja uskomuksiin omasta pärjäämisestään ja etenemisen mahdollisuuksistaan yhteiskunnassa. Näin lapsiperheiden eriarvoisuus tulee näkyväksi myös lasten ja nuorten kokemusten kautta.

Perhemuodolla ja perheeseen kuulumisella on selkeä yhteys yksilön taloudellisiin ja sosiaalisiin resursseihin sekä hyvinvointiin, minkä vuoksi muutokset lasten perhemuodoissa ja perhedynamiikassa ovat erittäin relevantti, joskin aikaisemmassa köyhyystutkimuksessa vähemmälle huomiolle jäänyt tutkimuskohde. Marika Jalovaaran erinomainen erkanevia elämänkulkuja käsittelevä artikkeli osoittaa, että suomalaisten lasten ja nuorten perhekokemuksissa on valtavia eroja. Esimerkiksi korkeakoulutettuihin naisiin verrattuna vähemmän koulutettujen naisten lapset syntyivät lähes neljä kertaa todennäköisemmin yksihuoltajaperheeseen ja tyypillisesti vähemmän koulutettujen vanhempien lapset kokivat enemmän muutoksia perherakenteessaan nuoruuden ja lapsuuden aikana. Kun viime vuosina syntyneistä kohorteista huomattava osa lapsista kasvaa yhden huoltajan perheissä, mikä on riski sosioekonomiselle haavoittuvuudelle, on julkisen hallinnon ja poliittisen päättäjien tärkeää ylläpitää ja kehittää hyvinvointipolitiikkaa sekä käytäntöjä, jotka korvaavat perherakenteen muutoksiin linkittyvää resurssien menettämistä ja torjuvat epäsuotuisten perhekokemusten seurannaisvaikutuksia esimerkiksi lasten ja nuorten koulutus- ja työuriin.

Teos päättyy toimittajien kirjoittamaan johtopäätösosioon, joka kokoaa yhteen edellisten lukujen antia ja jossa esitetään joitakin keskeisiä politiikkasuosituksia ja toimenpide-ehdotuksia köyhyyden ja huono-osaisuuden torjumiseksi. Toimenpide-ehdotusten osalta korostuu yleisesti viesti siitä, että lapsiin on syytä investoida ajoissa. Lapsiperheisiin kohdistuvien tulonsiirtojen jäädyttäminen tai leikkaaminen sekä erityisesti lyhyen tähtäimen säästöt lasten ja lapsiperheiden peruspalveluissa eivät ole pitkällä aikavälillä kustannustehokkaita. Sen sijaan ne ovat johtaneet pitkän aikavä- 
lin kohonneisiin kustannuksiin - sekä inhimillisesti että taloudellisesti. On syytä muistaa, että panostuksilla lapsiin ja nuoriin sekä laajemmin perhe- ja koulutuspolitiikkaan voi olla parhaimmillaan merkittävä tuottopotentiaali ja kauaskantoisia positiivisia seurauksia.

Kaiken kaikkiaan Lapsiperheiden köyhyys ja huono-osaisuus on kattava käsikirja edelleen ajankohtaisesta ilmiöstä. Teos on selkeästi kirjoitettu ja huolellisesti yhteen punottu kokonaisuus, joka etenee johdonmukaisesti, ja lapsiperheisiin paikantuvaa köyhyyttä ja huonoosaisuutta käsitellään monipuolisesti ja rikkain empiirisin aineistoin.Yksi ansiokkaan kokoomateoksen puute on, että laadullinen lähestymistapa lapsiperheiden köyhyyteen ja huono-osaisuuteen on sivuutettu.

Kirja on erinomaista luettavaa jokaiselle aihepiiristä kiinnostuneelle. Erityisesti sitä voi suositella sosiaalialan työntekijöille ja toimijoille, jotka ovat kosketuksissa lapsiperheitä koskevan köyhyyden ja huono-osaisuuden kanssa sekä opiskelijoille, joille teos avaa laajapohjaisesti köyhyyteen ja huono-osaisuuteen liittyviä kysymyksiä useista eri näkökulmista. Suotavaa olisi, että myös poliittiset päättäjät tarttuisivat teokseen.

\section{KANSAINVÄLISTÄ SOSIAALIPOLITIIKKAA VERTAILEVALLA OTTEELLA}

\section{Lauri Heimo: väitöskirjatutkija, Tampereen yliopisto}

Michael Hill \& Zoë Irving: Exploring the world of social policy: an international approach. Policy Press, Bristol. 2020, 241 s.

Globaalin tai kansainvälisen sosiaalipolitiikan alle laskettavien teosten määrä on kasvanut tasaisesti viimeisen parin vuosikymmenen ajan. Sosiaalipolitiikan tutkijoina kokeneet ja meritoituneet Michael Hill ja Zoë Irving tuovat tähän kirjallisuuteen tervetulleen lisän. Kirjoittajien mukaan tavoitteena on ollut tuottaa edistyneille opiskelijoille teos, joka heijastelisi sosiaalipolitiikan alalla siirtymää OECD-maiden edustamien kehittyneiden hyvinvointivaltioiden tutkimuksesta kohti kiinnostusta sosiaalipolitiikkaan "hyvinvointivaltiota" laajemmin. Kirjoittajien mukaan "siellä missä yhteiskunnallista edistystä on tapahtunut, sosiaalipolitiikalla on ollut keskeinen rooli näissä saavutuksissa. Sosiaalipolitiikan analyy$\sin$ usein rajoittuessa vakiintuneisiin sosiaaliturvainstituutioihin, tulevat sosiaalipolitiikan moninaiset järjestelyt ja kontribuutiot virallisten rakenteiden ulkopuolella vähemmän tunnistetuiksi, tai vähintäänkin heikommin sisällytetyiksi keskusteluihin politiikkatoimista" (s. 2).

Globaalin ja/tai kansainvälisen sosiaalipolitiikan kirjallisuuden on voinut karkeasti jakaa kolmeen eri "tyylisuuntaan": 
1. Kansainvälisiin järjestöihin sekä globaaliin hallintaan perustuva suuntaus.

2. Sosiaalipolitiikan kehitysulottuvuuksiin globaalissa etelässä keskittyvä näkökulma.

3. Hyvinvointi(valtio)regiimejä ja sosiaalipolitiikkatoimia OECD kontekstin ulkopuolella tarkastellut ote.

Yhdistäessään vertailevaa ja globaalia sosiaalipolitiikkaa käsillä oleva teos ei osu tyylipuhtaasti mihinkään näistä lokeroista. Kirja tarjoaa lukijalle kattauksen sosiaalipolitiikan keskeisistä teemoista ja osa-alueista kansallisvaltioiden rajat ylittävästä näkökulmasta. Pyrkimyksenä on tarkastella näitä osa-alueita myös maantieteellisesti kattavasti. Yhdistävä tekijä Hillin ja Irvingin tulokulman ja suurelta osin yllä mainittujen tyylisuuntien välillä on irtisanoutuminen metodologisesta nationalismista. Sosiaalipolitiikan ilmiöitä avataan kirjassa pikemminkin metodologisen transnationalismin viitekehyksestä painottaen valtioiden rajat läpileikkaavia instituutioita, linkkejä ja aktiviteetteja. Näin keskitytään niihin vaikutuksiin, joita globaaleilla poliittisilla prosesseilla, toimijoilla ja instituutioilla on kansallisiin hyvinvointivaltioihin, sosiaaliturvajärjestelmiin ja sosiaalipoliittisiin toimiin.

Ajatus sosiaalipolitiikan eri osa-alueiden tarkastelusta globaaleja keskusteluja ja monipuolisia maaesimerkkejä hyödyntäen on kiinnostava ja kaivattu näkökulma sosiaalipolitiikan kirjallisuuteen. Kirja on rakenteeltaan selkeä ja koostuu johdannon ja johtopäätösten lisäksi kahdesta osasta, joista ensimmäisessä kirjoittajat käsittelevät kolmen luvun verran sosiaalipolitiikan ja sen kansainvälisen ulottuvuuden hahmottamiseksi keskeisiä teemoja ja näkökulmia. Toisessa osiossa siirrytään tarkastelemaan sosiaalipolitiikan eri osa-alueita.

Johdanto aloittaa kirjan näkökulman avaamisen selventämällä otsikossa esiintyvän world of social policy merkitystä. Viittaamalla sosiaalipolitiikan "maailmaan" kirjoittajat avaavat kolme eri ulottuvuutta kirjan lähestymistavan ymmärtämiseksi. Ensimmäinen on nyökkäys regiimitutkimuksen ja erityisesti Esping-Andersenin suuntaan. Näin kirjoittajat käsittelevät vertailevan hyvinvointivaltiotutkimuksen ja regiimitypologisointien selitysvoimaan liittyviä ongelmia kun analysoidaan maita "kehittyneiden hyvinvointivaltioiden ulkopuolella". Toiseksi Hill ja Irving tuovat esiin sosiaalipolitiikan maantieteellisen ulottuvuuden ja kirjan tavoitteen tarkastella sosiaalipolitiikan teemoja ja osa-alueita tukeutuen esimerkkeihin maapallon eri alueilta. Kolmanneksi tekijät viittaavat akateemiseen sosiaalipolitiikkaan ja tavoitteeseen laajentaa sen tarkastelukohteita oppiaineena kansainväliseen ja globaaliin suuntaan. Johdanto toimii mainiosti ja antaa odottaa teosta, jossa sosiaalipolitiikkaa käsitellään maailmanlaajuisena kokonaisuutena niin, että maaesimerkeissä ja keskeisten teemojen ja keskustelujen osalta olisi mahdollista puhua aidosti globaalista perspektiivistä.

Ensimmäisessä osassa kirjoittajat tarjoavat lukijalle kolme tulkintakehystä kansainväliseen sosiaalipolitiikkaan: 1) Eriarvoisuus (Inequalities and why they matter), 2) Sosiaaliturvan eri muodot (Varieties of welfare) ja 3) Politiikka- 
prosessit (Policy processes). Tämä osuus kirjassa toimii varsin hyvin, ja erityisesti politiikkaprosessien nostaminen keskeiseksi näkökulmaksi saa tältä lukijalta kiitosta. Tässä vaiheessa alkaa kuitenkin jo näkyä merkkejä siitä, että näkökulmat pohjaavat vahvasti Britannialle, Yhdysvalloille ja Euroopalle relevantteihin keskusteluihin.

Toisessa osassa sosiaalipolitiikan osaalueista käsittelyyn on otettu toimeentuloturva (income security), työ, koulutus, asuminen, terveys, hoiva (social care) ja ympäristö. Teemoja ei ole tarkoitus käydä kattavasti läpi luoden globaalia sosiaalipolitiikan ensyklopediaa, vaan ajatuksena on ollut tarttua muutamiin kansainvälisen keskustelun kannalta keskeisiin teemoihin ja maavertailuihin näiden osa-alueiden sisällä.

Kirjalle asetettu tehtävä siirtyä tarkastelemaan sosiaalipolitiikkaa OECDmaita ja hyvinvointivaltiota laajemmin ei ole helppo. Kirjan nojatessa pitkälti vertailevaan otteeseen maiden välillä nousee tilastojen ja aiemman tutkimuksen rooli suureksi, ja kuten kirjoittajat itse myös toteavat, kattavaa dataa ei yksinkertaisesti kaikista maista ole saatavilla. Silti täytyy hieman ihmetellä luvusta toiseen toistuvaa OECDmaiden vertailua ottaen huomioon, että kirjan yhdeksi keskeiseksi tehtäväksi on nostettu sosiaalipolitiikan maantieteellisen tarkastelun laajentaminen koko maapallon käsittäväksi.

Myös aiempaa tutkimusta niin sanotusta globaalista etelästä on kirjassa käsiteltyjen sosiaalipolitiikan lohkojen osalta selvästi vähemmän kuin pohjoisesta. Näin ollen aiemman kirjallisuuden pohjalta esitetyt taksonomiat ja tyypittelyt kattavat usein vain OECD-maat (paikoin mukaan lukien vain vauraimmat ja aiemmin OECD-statuksen saaneet maat). Ajoittain myös OECD:n ulkopuolinen maailma on edustettuna näissä tilastoissa ja vertailuissa, mutta syvemmät sosiaalipolitiikkatoimien tarkastelut luotaavat OECD-maita - niiden eroja ja samankaltaisuuksia ja niissä relevantteja keskusteluja. Muulle maailmalle jää vain pieni rooli lähinnä muistutuksena siitä, että tässä kirjassa piti tarkastella muitakin maita. Muutamissa luvuissa tarkastellaan lähes yksinomaan OECD-maita (terveys, asuminen, hoiva). Lisäksi tuntuu kuin kirja olisi kirjoitettu ensisijaisesti brittiyleisölle. Kirjoittajat ovat tehneet uransa IsonBritannian yliopistoissa ja tutkineet Britannian sosiaalipolitiikkaa, joten lienee ymmärrettävää, että saarivaltion sosiaalipoliittiset keskustelut ovat kirjassa vahvassa roolissa. Kansainvälistä sosiaalipolitiikkaa tarkastellessa on Britannia kuitenkin maaesimerkeissä vahvasti yliedustettuna. Niukaksi jäävä keskustelu OECD-maiden ulkopuolelta rajaa kirjassa myös sosiaalipolitiikan moninaiset järjestelyt ja kontribuutiot virallisten rakenteiden ulkopuolella melko pieneen rooliin.

Käsittelyyn nostetaan laajoja teemakokonaisuuksia koulutuksesta terveys- ja asumispolitiikkaan. Teos olisi mielestäni hyötynyt osa-alueiden rajaamisesta tai niiden globaalisti laajennetusta tarkastelusta. Toimeentuloturvan osuus on pari sivua pidempi kuin muiden, mutta itse olisin mielelläni nähnyt hieman laajemman keskustelun aiheesta. Viimeisen kolmen vuosikymmenen aikana useat alhaisen ja keskitulon maat 
ovat ryhtyneet rakentamaan tai laajentamaan aiemmin purettuja sosiaaliturvajärjestelmiään, ja keskeisessä roolissa sosiaaliturvauudistuksissa ovat olleet erilaiset maksuihin perustumattomat perusturvaetuudet. Kirjassa nämä saavat puolen sivun mittaisen käsittelyn ja taksonomia eri perusturvaetuuksista (social assistance) on vuodelta 1995 olevasta lähteestä ja käsittää vain eurooppalaisia kehittyneitä hyvinvointivaltioita (ja Turkin). Aiheesta on kuitenkin kirjoitettu paljon ja dataakin olisi saatavilla.

Alhaisen ja keskitulon maissa on luotu hyvinvointivaltioiden perustuksia samanaikaisesti "läntisten" hyvinvointivaltioiden kanssa ja viimeisen kolmen vuosikymmenen aikana lukuisat maat OECD:n ulkopuolella ovat laajenta- neet sosiaaliturvaansa merkittävästi Sosiaalipolitiikan kirjallisuudessa on taipumusta tarkastella joko yleisesti sosiaalipolitiikkaa, jolloin keskiössä ovat juuri OECD-maat, tai spesifisti sosiaalipolitiikkaa kehityskonteksteissa. Hill ja Irving tekevät tervetulleen kontribuution tavoitteessaan tuoda OECDmaiden ulkopuolinen sosiaalipolitiikka, valtioiden rajat ylittävät politiikkaprosessit ja "epäviralliset" sosiaaliturvan järjestelyt osaksi sosiaalipolitiikan laajempaa tarkastelua. Tässä tehtävässä teos onnistuu osittain. Kirja soveltuu laajasti globaaleista kysymyksistä ja moninaisista sosiaaliturvan muodoista kiinnostuneille ja sosiaalipolitiikan kirjallisuuteen jo hieman perehtyneille lukijoille. Kirjan keskeinen sisältö painottuu kuitenkin valitettavan vahvasti OECD-maihin. 